\title{
正弦波励振装置の振動特性の検討*
}

尾林 康司

\section{Investigation of Vibration Characteristics of Excitation Equipment*}

Kouji OBayAshi $^{\dagger}$, Yoshitomo OKadA ${ }^{\dagger}$ and Kazuaki Kitamura ${ }^{\dagger}$

\section{1.まえがき}

近年, 交・直流励磁した二相誘導電動機は, 正弦波励 振装置として, 角加速度計の角加速度較正 [1], 慣性モー メントの実測装置 [2], 攪拌機, 洗浄器および貴金属・宝 石類または装飾品等の研磨機 [3] の励振源として広く利 用されるかまたは，利用されようとしている。したがっ て, この交・直流励磁した二相誘導電動機を励振装置と して利用するのに当たっては, 本励振装置の振動特性を 解明し, 本励振装置の特徵やその有用性等を明らかにし ておく必要がある。

本速報では, このような現状を考慮し, 交・直流励磁 した二相誘導電動機の実用振動トルク計算式に基づき励 振装置の各種振動特性を検討・考察する。すなわち, (1) 振動周波数一振動トルク特性および(2)振動周波数一振動 振幅特性をそれぞれ定量的に検討および考察し, 交・直 流励磁した二相誘導電動機, 特に二相サーボモー夕を主 体とした正弦波励振装置が, 可変振動周波数, 可変振動 振幅正弦波励振装置として十分に実用に供しうることを 明らかにする。

\section{2. 実用振動トルク計算式 [4]}

交・直流励磁した二相誘導電動機の実用振動トルク計 算式は，次式で与えられることが知られている。

$$
\begin{aligned}
& T_{v}=\frac{\sqrt{2} x_{m}^{2} V_{m} I_{d c} \cos \left(\omega_{i} t-\Phi\right)}{(4 \pi f / P) \sqrt{\left\{r_{1} r_{2}-x_{1}\left(x_{2}+x_{m}\right)-x_{2} x_{m}\right\}^{2}}} \\
& \overline{\overline{+\left\{r_{1}\left(x_{2}+x_{m}\right)+r_{2}\left(x_{1}+x_{m}\right)\right\}^{2}}} \\
& \text { ここに, } \Phi=\tan ^{-1} \frac{x_{2}}{r_{2}} \\
& \text { ここで } \\
& f \text { : 電源周波数 }[\mathrm{Hz}]
\end{aligned}
$$

* 原稿受付 2000 年 12 月 18 日

$\dagger$ 足利工業大学 工学部 Faculty of Engineering, Ashikaga Institute of Technoloy; 268 Omae-cho, Ashikaga city, Tochigi 326-8558, JAPAN

Key Words: excitation equipment, vibrational amplitude, alternating torque, two-phase induction motor, vibrator.

$$
\begin{aligned}
& P: \text { 極数 } \\
& V_{m}: \text { 交流印加電圧 }[\mathrm{V}] \\
& I_{d c}: \text { 直流励磁電流 }[\mathrm{A}] \\
& r_{1}: \text { 一次抵抗 } \\
& x_{1}: \text { 一次漏れリアクタンス } \\
& x_{m}: \text { 励磁リアクタンス } \\
& x_{2}: \text { 二次漏れリアクタンス } \\
& r_{2}: \text { 二次抵抗 }
\end{aligned}
$$

すなわち, 上記 (1) 式に, 供試機の等価回路定数, 印 加交流電圧および直流電流を適用することにより，交・ 直流電圧印加時に発生する二相誘導電動機の振動トルク を容易に算定することができる。すなわち, 上記 (1) 式 に基づき正弦波励振装置の振動トルク特性等の検討・考 察を行うことが可能である.

\section{3. 振動特性の検討および考察}

ここでは，実用振動トルク計算式 (1) 式に基づき，正 弦波励振装置の振動特性の検討および考察を行う。すな わち, 交・直流励磁した二相誘導電動機の(1)振動周波 数一振動卜ルク特性および(2)振動周波数一振動振幅特性 をそれぞれ定量的に検討および考察する。

Fig. 1 は, Table 1 に示した等価回路定数を持つ供試 機 A, B (二相サーボモー夕) および C, D (汎用機) の $V_{m} / f=0.5,1.0,1.5,2.0, I_{d c}=150[\mathrm{~mA}]$ および振 動周波数 $f=10 \sim 150[\mathrm{~Hz}]$ 時の振動周波数 $(f)$ - 振動 トルク $\left(T_{v}\right)$ 特性を算定し, その算定結果と振動トル クの実測值を併記したものである。なお，各供試機の $f=50[\mathrm{~Hz}]$ 時の定格電圧は $100[\mathrm{~V}]$ である.

Fig. 1 より, $T_{v}$ は $f$ の増大に伴って, いずれの供試機 の場合も同様の $f-T_{v}$ 特性を示すことが分かる.すな わち $T_{v}$ は $f$ の増大に伴って, 次第に増大する傾向を示 し, その増大の割合は $V_{m} / f$ のきいもの程, 大きくな ることが分かる.そして, $T_{v}$ は, 電動機出力の大きいも の程大きく, また $T_{v}$ の大きさは, 同出力の電動機であっ ても，二相サーボモータの場合よりも沉用機の場合の方 が大きくなる傾向が見られる.

Fig. 2 ないし 3 は, 前者と同算定条件時の振動周波数 


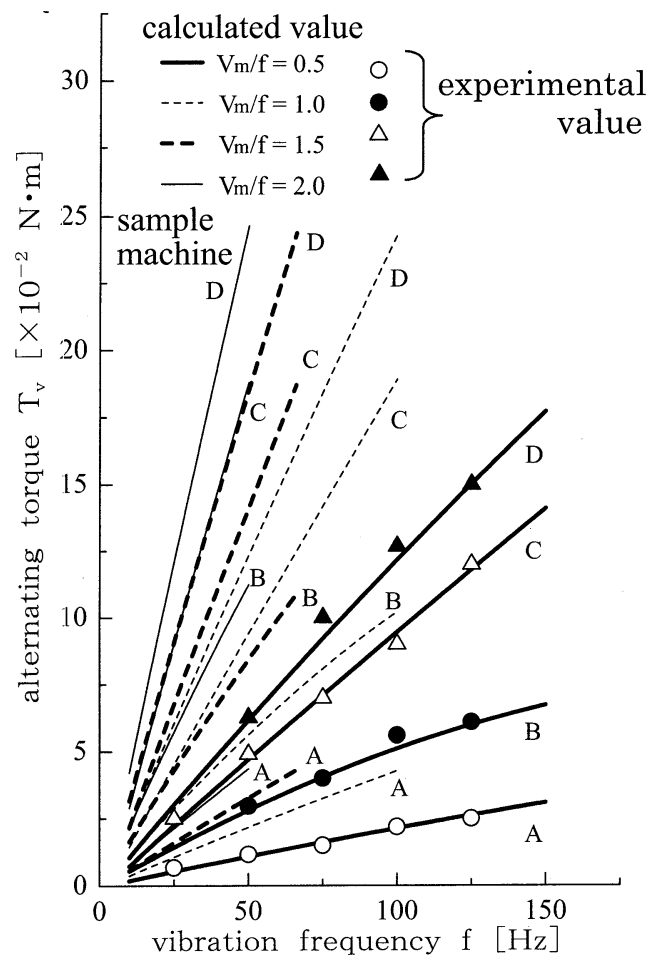

Fig. 1 Vibration frequency vs. alternating torque characteristics

Table 1 Equivalent circuit parameters $[f=50 \mathrm{~Hz}]$

\begin{tabular}{|c|c|c|c|c|c|c|}
\hline \multirow{2}{*}{$\begin{array}{c}\text { Sample } \\
\text { machine }\end{array}$} & \multirow{2}{*}{$\begin{array}{c}\text { Rated } \\
\text { output } \\
{[\mathrm{W}]}\end{array}$} & \multicolumn{5}{|c|}{$\begin{array}{c}\text { Equivalent circuit } \\
\text { parameters }[\Omega]\end{array}$} \\
\cline { 3 - 7 } & & $r_{1}$ & $x_{1}$ & $x_{m}$ & $x_{2}$ & $r_{2}$ \\
\hline $\mathrm{A}$ & 3 & 132 & 133 & 793 & 20 & 938 \\
\hline $\mathrm{B}$ & 10 & 70 & 95 & 662 & 10 & 279 \\
\hline $\mathrm{C}$ & 3 & 288 & 16 & 866 & 16 & 283 \\
\hline $\mathrm{D}$ & 10 & 136 & 14 & 461 & 14 & 109 \\
\hline
\end{tabular}

A, B: two-servomotor, C, D: ready-made machine

$(f)$ 一振動振幅 $\left(\theta_{n}\right)$ 特性を

$$
\theta_{m}=\frac{T_{v}}{J \omega_{i}^{2}} \quad[\mathrm{rad}]
$$

$$
\text { ここに, }
$$

$T_{v}$ : 供試機の発生する振動トルクの大きさ $[\mathrm{N} \cdot \mathrm{m}]$

$J$ : 供試機の回転子慣性モーメント $\left[\mathrm{Kg} \cdot \mathrm{m}^{2}\right]$

$\omega_{i}:$ 振動角速度 $(=2 \pi f)$

より算定し，その算定結果と振動振幅の実測值 [5] を併 記したものである。

Fig. 2 ないし 3 より, $\theta_{m}$ は $f$ の増大に伴っていずれの 供試機の場合も指数関数的な減少傾向を示すことが分か る。すなわち，交・直流励磁した二相誘導電動機を用い た正弦波励振装置は, 振動周波数の減少に伴って, 次第 に小振動振幅のものから, 大振動振幅のものへと大幅に 振動振幅犬゙変化することが分かる。そしてこの振動振幅 は, $V_{m} / f$ が大きい場合程大きくかつ, 回転子慣性モー

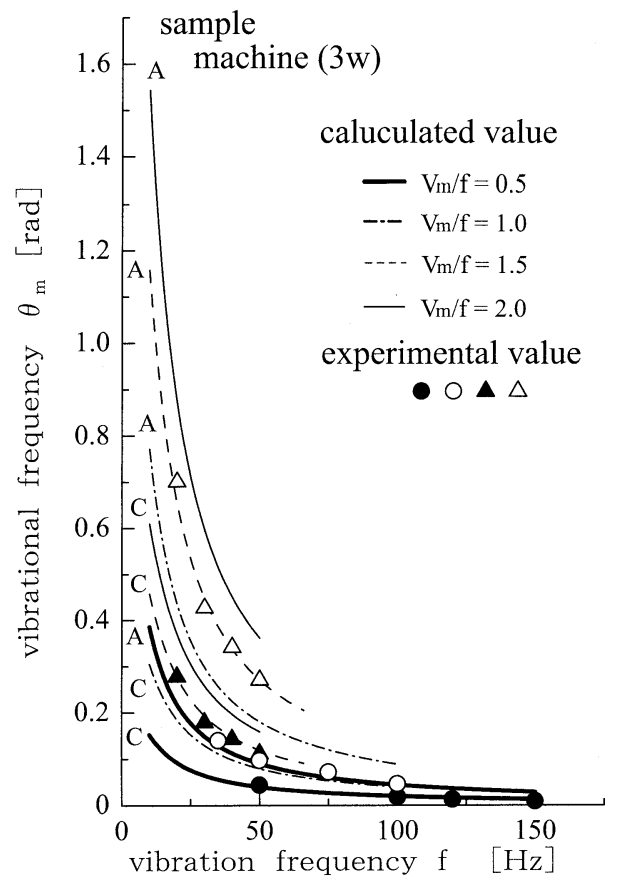

Fig. 2 Vibration frequency vs. vibrational amplitude characteristics

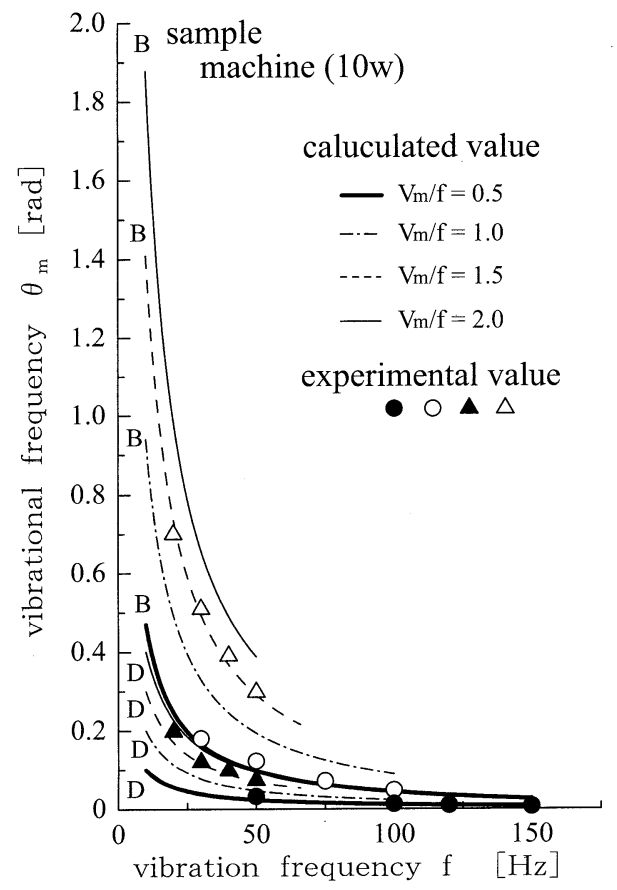

Fig. 3 Vibration frequency vs. vibrational amplitude characteristics

メントの小さい, すなわち二相サーボモータ (A，B機) の場合の方が汎用機 $(\mathrm{C}, \mathrm{D}$ 機) のものよりもかなり大き くなることが分かる。これは，同出力の電動機であって も, 二相サーボモータの回転子慣性モーメントの方が汎 用機のものよりもかなり小さいことに起因している.し たがって，大振動振幅の正弦波励振装置として利用する には，二相サーボモータを主体とした励磁装置の方が汎 
用機を使用した装置よりも，望ましい結果が得られるこ とが分かる。なお，各供試機の慣性モーメント $(J)$ は， それぞれ $\mathrm{A}$ 機: $J_{A}=1.22 \times 10^{-6}\left[\mathrm{Kg} \cdot \mathrm{m}^{2}\right], \mathrm{B}$ 機 : $J_{B}=$ $2.94 \times 10^{-6}\left[\mathrm{Kg} \cdot \mathrm{m}^{2}\right], \mathrm{C}$ 機: $J_{C}=1.2 \times 10^{-5}\left[\mathrm{Kg} \cdot \mathrm{m}^{2}\right], \mathrm{D}$ 機: $J_{D}=2.66 \times 10^{-5}\left[\mathrm{Kg} \cdot \mathrm{m}^{2}\right]$ であった。

以上の各振動特性の検討および考察結果より, 交・直流 励磁した二相誘導電動機（二相サーボモータ）を用いた 正弦波励振装置は, $f=10 \sim 150[\mathrm{~Hz}]$ の範囲内で, 振動周 波数を変えることにより小振動振幅 $\left(\theta_{m} \doteqdot 0.008[\mathrm{rad}]\right)$ から大振動振幅 $\left(\theta_{m} \fallingdotseq 1.80[\mathrm{rad}]\right)$ に至る正弦波振動を 容易に発生し得ることが分かった. すなわち, 本正弦波 励振装置は可変周波数, 可変振動振幅正弦波励振装置と して実用に供しうることが明らかになった。

\section{4. あとがき}

本速報では, 交・直流励磁した二相誘導電動機を用い た正弦波励振装置の各種振動特性を定量的に検討および 考察し, 二相サーボモータを主体とした正弦波励振装置 が, 可変周波数, 可変振動振幅正弦波励振装置として十
分に実用に供しうることを明らかにした。

\section{参考文献}

[1] 須藤, 篠宮, 戸恒, 梅沢: 二相誘導発電機形加速度計の基 礎特性の検討 ; 制御工学, Vol. 11, No. 6, pp. 308-313 (1967)

[2] 尾林, 岡田, 前田, 土井 : 慣性モーメントの一実測装置; システム制御情報学会論文誌, Vol..11, No. 3, pp. 157159 (1998)

[3] たとえば，杉浦：磁気バレル研磨機による加工の現状 ; 機械と工具, pp. 33-37（1996）

[4] 岡田, 前田, 尾林 : 交 ·直流電圧印加時の二相誘導電動 機の振動トルク計算式; システム制御情報学会論文誌, Vol. 10, No. 9, pp. 502-504 (1997)

[5] 岡田, 尾林, 北村, 大澤 : 振動振幅の一実測法 ; システ ム制御情報学会論文誌, Vol. 13, No. 7, pp. 346-347 (2000)

[6] 尾林, 岡田, 北村, 大澤: 正弦波励振装置の振動トルク の解析とその検討; 電気学会回転機研究会, RM-00-147 (2000) 